九州大学学術情報リポジトリ

Kyushu University Institutional Repository

\title{
A Systematic Review of Green Human Resource Management
}

\section{Shahriari, Bahareh}

Human Resource Management, Kharazmi University : Doctoral Program

Hassanpoor, Akbar

Human Resource Management, Faculty of Management, Kharazmi University : Assistant Professor

Navehebrahim, Abdolrahim

Educational Administration, Faculty of Management, Kharazmi University : Professor

Jafarinia, Saeed

Human Resource Management, Faculty of Management, Kharazmi University : Assistant Professor

https://doi.org/10.5109/2328408

出版情報：Evergreen. 6 (2)，pp.177-189，2019-06. 九州大学グリーンテクノロジー研究教育センター バージョン：

権利関係 : 


\title{
A systematic review of Green Human Resource ${ }^{1}$ Management
}

\author{
Bahareh Shahriari $^{1}$, Akbar Hassanpoor ${ }^{2 *}$, Abdolrahim Navehebrahim ${ }^{3}$, Saeed Jafarinia ${ }^{2}$ \\ ${ }^{1} \mathrm{PhD}$ student of Human Resource Management, Kharazmi University, Tehran, Iran \\ ${ }^{2}$ Assistant Professor of Human Resource Management, Faculty of Management, Kharazmi University, Tehran, Iran \\ ${ }^{3}$ Professor of Educational Administration, Faculty of Management, Kharazmi University, Tehran, Iran
}
*Author to whom correspondence should be addressed, E-mail: a.hassanpoor@khu.ac.ir

(Received February 26, 2019 accepted June 10, 2019).

\begin{abstract}
The purpose of this research was to present a systematic review of literature on green human resource management over the past ten years, which was the best way to share useful research data for researchers and managers and develop the literature in this field. We have identified the factors, the functions and the amount of attention to them and the gaps. The results represented that the selection and recruitment, training and development functions with $87.5 \%$ and $75 \%$ had the highest attention and discipline management and socialization with $6.25 \%$ and $3.12 \%$, had the least attention. The main gaps were the lack of comprehensive studies and research about GHRM in undeveloped countries and Asia and also a cross-cultural model.
\end{abstract}

Keywords: Green management, Green human resource management, systematic literature review.

\section{Introduction}

The issue of environmental sustainability and green organizations is increasingly being developed in management plan ${ }^{15,61)}$ It creates a green revolution in specific, traditional ways ${ }^{24)}$, such as human resources ${ }^{37}$, ${ }^{20)}$. Recently In the field of human resources, the issue of HR green management has emerged $22,37,36$, which has identified itself as a new research line ${ }^{54,55,56,57)}$ and is becoming a new competitive dimension ${ }^{58}$. The goal of the sustainability model in working life is to enhance the adaptability and welfare capacities of the working systems and their employees. Sustainability of human resource management can be examined from four sociological, psychological, strategic and environmental perspectives, whose environmental perspective refers to green human resource management (GHRM) ${ }^{44)}$.

The term "green" has different meanings; however, it often means something that is related to the nature or natural environment. Lee has called Green Management a method by which organizations manage the environment through the development of environmental strategies ${ }^{23)}$. A Green Company is an organization that offers products and services it is in line with the goal of more efficient use of resources, generating renewable energy sources, reducing greenhouse gas emissions and minimizing environmental impact. Green human resources are an attempt to meet needs; as a result, there is a balance between organizational growth for wealth generation and natural environment protection that possible to build a successful future ${ }^{7}$.
Green management, with emphasis on environmental protection, including preserving water, air, soil, and the use of clean energies and renewable natural resources, will create significant opportunities for cost savings in goods and services and reduces the negative and destructive effects on the environment ${ }^{41}$. At present, employees tend to work in such organizations and feel happy that they are green ${ }^{15}$. Further, organizational strategies for environmental management and sustainable development will succeed when they are well-aligned with its human resource practices ${ }^{62,63,64)}$.

The term "green human resource management" is a new concept for the majority of academic and professional specialists in the field of human resource management. Such a topic was based in 1996 in the light of the features proposed by Wehrmeyer ${ }^{52)}$, in which he edited a book entitled "Green People: Human Resources and Environmental Management". The human capital and its management are instrumental to the fulfilment of Green objectives ${ }^{75}$. In recent years, other studies have been conducted by other researchers, including Jabbour, Renwick, Jackson, and Ehnert; however, these studies have taken place in other countries. It became clear that organizations needed the support of human resource practices, such as training, performance evaluation, and rewards, to implement greening ${ }^{59)}$.

The need for HRM support for green issues was reinforced by works discussing more broadly the positive effects of human resources to firms' performance ${ }^{60)}$. By utilizing Green Human Resource Management, we will get benefit from its positive outcomes, which will, in

\footnotetext{
${ }^{1}$ This Article has been extracted from the doctoral thesis
} 
addition to protecting the environment, increase productivity and have positive financial implications ${ }^{68)}$, including:

- Growth, well-being and employee health ${ }^{11,30,18)}$.

- Increased employee creativity and changeability ${ }^{43)}$

- Balance between financial performance and environmental protection ${ }^{7,31}$.

- Attracting more skilled staff due to the better image of the organization in the community, the maintenance of skilled staff and increased incentives, their commitment and loyalty to the relevant organization and increased competitive advantage $1,15,27,37,38,30,21)$.

- Reducing water and energy consumption, reducing paper consumption, reducing waste and even recycling and using them for fertilizer, all of which reduces costs 32).

- Reducing transportation, which reduces air pollution and reduces costs $32,37,27)$.

- Reducing environmental degradation effects ${ }^{41}$.

- Building a green work environment ${ }^{32}$ ).

- Reducing CO2 ${ }^{46)}$.

- Promoting green culture and green lifestyle in society 27, 40,2, 21).

Also; among the negative consequences that we may experience, lack of attention is to properly motivate individuals or even to advantage their negative ones which disrupt green performance and results in what is expected to be achieved which should be given special attention ${ }^{37)}$.

The purpose of this article, a systematic review of green human resources management and the study of research in this regard over the past 10 years, to this end, in addition to developing the literature in this field, by examining the findings of other researchers and their research results, it will be shown how far the previous researchers have focused on the factors affecting the implementation of Green Human Resource Management, its functions and gaps, so that future researchers can contemplate further gaps. Managers and professionals can also use the results of previous research, effective factors and practices used in accordance with their organization's requirements. By systematically reviewing related articles, research can be divided into different categories:

1- Some researches such as Tavakoli et al. ${ }^{49)}$, Seyed Javadin et al. ${ }^{42)}$, Mohammad Nejad et $\mathrm{al}^{29}$, Mishra ${ }^{28}$, Renwick et $\mathrm{al}^{37)}$ Both the functions of Green Human Resource Management and the effective factors in its implementation have been examined and referred to existing gaps. 2. Some other researchers, including Patil and Sarode ${ }^{53)}$, Guerci and Carollo ${ }^{16)}$, Tariq et al. ${ }^{48)}$, Milliman ${ }^{27)}$, Dabois and Dabois ${ }^{9)}$, only worked on the functions of Green Human Resource Management and its implementation factors.
3. The other group only deals with the existing factors and gaps such as Hassanpoor et al. ${ }^{19)}$, Jabbour and Jabbour $^{21)}$, Haddock et al ${ }^{17)}$.

4. Another group has also implemented functions and gaps such as Tang et al. ${ }^{47)}$, Masri and Jarron ${ }^{26)}$

5. Paro Ragas et al. ${ }^{33)}$ And Marques Periera et al. ${ }^{25)}$ Have focused on Gaps.

6. Some scholars, like Abbasi et al. ${ }^{1)}$, only expressed the functions (Table 3).

Therefore, by examining past researches and categorization, conducting a research with a firm commitment to a systematic review of previous research and its conclusion and review of all functions, implementation factors and gaps in the field of human resource management are also needed to improve human resource management of organizations, to take advantage of both its benefits and environmental sustainability. Because of the fact that; the topic of Green Human Resource Management is a startup topic in our country and the number of researches carried out in the country, in this case, are small and on the other hand, so far, a systematic overview of the functions, factors, and gaps related to green human resources management has not been done so. Therefore, we have tried to review systematic reviews of published articles related to human resource management over the past ten years and present the results of this research to interested researchers, students and managers who wish to promote their green activities in their organization to play a greater role in promoting green culture and environmental protection. Of course, it is worth mentioning that the current research differs from previous systematic review researches because it has a comprehensive review at the researches and aspects of the GHRM and is not limited to a single area or specific areas and all items are included. For example, Ahmad (2015) ${ }^{2)}$ in his research has just studied on GHRM practices \& policies or Renwick et al. (2012) ${ }^{37)}$ have shown how organizations develop Green abilities and provide employees with opportunities to be involved in EM organizational efforts, Patil \& Sarode $(2018)^{53)}$ mentioned the role of HR in developing the sustainability and protecting natural resources and also investigated the role of managers in different levels of organization and their staff in implementing green behavior, Tariq et al. $(2016)^{48)}$ researched on Empowerment Factors in GHRM and have expressed the objectives and findings of some of the past researches between 1988 and 2013 and Opatha and Arulrajah $(2014)^{32}$, provided simplified general reflections in respect of GHRM in Sri Lanka.

In the context of green human resources management, there are many definitions given in Table 1 that summarize these definitions and the views expressed in this regard: 
Table 1: Definitions of GHRM

\begin{tabular}{|c|c|}
\hline Tang et al., (2018) & $\begin{array}{l}\text { He considers GHRM as a scale for credibility and development which } \\
\text { results in employees' green behavior and awareness through the adoption of } \\
\text { a green perspective and making use of green communication channels. }\end{array}$ \\
\hline $\begin{array}{l}\text { Seyed Javadin et } \\
\text { al., (2017) }\end{array}$ & $\begin{array}{l}\text { They consider GHRM as an approach for sustainable investment and } \\
\text { development and state that through focusing on its human capital and } \\
\text { environment management plans, organizations obtain both their economic } \\
\text { and environmental goals. }\end{array}$ \\
\hline $\begin{array}{c}\text { Jabbour \& } \\
\text { Jabbour (2016) }\end{array}$ & $\begin{array}{l}\text { They believe that the functions and measures of GHRM are highly tangible } \\
\text { and cause green issues to be considered for in employees' daily tasks, and } \\
\text { also have positive effects on employees' lives and performances. }\end{array}$ \\
\hline $\begin{array}{l}\text { Renwick et al., } \\
\text { (2016) }\end{array}$ & $\begin{array}{l}\text { GHRM improves the credibility of organizations and causes the labor force } \\
\text { to show more willingness to stay in their organizations, and also causes } \\
\text { better labor forces to be willing towards getting recruited by green } \\
\text { corporations }\end{array}$ \\
\hline Ahmad (2015) & $\begin{array}{l}\text { GHRM is responsible for the creation of awareness, informing, and } \\
\text { establishment of interactions between the employees, especially regarding } \\
\text { environmental issues. In addition, through green policy making, it orients } \\
\text { the employees towards fulfilling their green duties. }\end{array}$ \\
\hline $\begin{array}{l}\text { Mohd Yusef } \\
\quad(2015)\end{array}$ & $\begin{array}{l}\text { He believes that GHRM is a complex set of the following counts: A- } \\
\text { Electronic GHRM: 1- electronic recruitment, 2-e-mails, 3- electronic } \\
\text { training, 4- electronic users, and 5- electronic job description; B- Flexible } \\
\text { Work including: 1- part-time job, and 2- working at home; C- Social } \\
\text { responsibility including: 1- recycling, 2- social responsibilities, and 3- } \\
\text { green cafeteria; D- Green Policies including: 1- security, well-being, } \\
\text { consideration for the environment, and 2-green organizational policies (ISO } \\
\text { 14001-2); E- Additional care programs including: Mothers' rooms and } \\
\text { parking lots, and 2- Childcare room. }\end{array}$ \\
\hline $\begin{array}{c}\text { Opatha \& } \\
\text { Arulrajah (2014) }\end{array}$ & $\begin{array}{l}\text { By GHRM it is referred to the entire activities involve with the } \\
\text { development, execution, and maintenance of a system aiming to keep green } \\
\text { employees in the organization. Transforming regular employees into green } \\
\text { employees is the duty of HRM and its aim is to achieve environmental } \\
\text { goals and ultimately to achieve a significant share in environmental } \\
\text { sustainability which points to methods, policies, and systems that benefit } \\
\text { individuals, societies, environments, and workplaces. }\end{array}$ \\
\hline Dutta (2012) & $\begin{array}{l}\text { GHRM is comprised of two main elements namely as the eco-friendly } \\
\text { functions of HR, and safekeeping of knowledge capital. He states that } \\
\text { GHRM is a resolution that helps with the creation of green labor forces who } \\
\text { are able to both perceive and appreciate green culture in their organizations. } \\
\text { Such a green innovation can apply its green goals to the entire process of } \\
\text { HRM in the contexts of recruitment, selection, training, compensation, } \\
\text { growth and development, and retention of HR }\end{array}$ \\
\hline
\end{tabular}

\section{Green Human Resource Management Functions}

\subsection{Green recruitment and employment:}

Human resources can prove their commitment to being green, with virtual screening, whenever possible, by recruiting job applicants instead of direct interviews. The scope of this effort can come from simple ways like Skype For initial screening interviews one by one to complex electronic methods (such as distance attendance) to conduct group interviews and virtual business exhibitions ${ }^{39)}$. Holtom, Mitchell, Lee, and Eberly (2008) in their study on turnover and retention of employees argue that the most important benefit dimensions of HR and sustainability are retention/recruitment and satisfaction. Firms are now beginning to recognize the fact that gaining a reputation as a green employer is an effective way to attract new talent ${ }^{69)}$, also; human resources can expand the idea by encouraging employees to use e-technologies such as remote conferencing technologies to host conferences, which otherwise require travel and costs these steps can all contribute to promoting the environmental culture of the corporate culture ${ }^{27)}$.

\subsection{Green Training \& Development:}

Human resources must ensure that initial preparation programs contain information about the organization's goals and practices, as well as how employees participate in environmental improvement programs and voluntary programs 4). Employee training is crucial for the successful implementation of the environmental management system and the creation of an environment friendly culture in the organization ${ }^{67)}$. Green training and development educate employees about the value of EM, train them in working methods that conserve energy, reduce waste, diffuse environmental awareness within the organization, and provide an opportunity to engage employees in environmental problem-solving ${ }^{70)}$. At Ellin Fisher's clothing company, new staff members 
learn about the company's values and plans from senior recruiters. The company reinforces the green message during lunch and in electronic content, as well as encouraging employees to participate in social awareness committees, community service events, and charity events ${ }^{40)}$.

\subsection{Green Performance Management:}

One of the first important steps human resources can take to develop a comprehensive green approach is encouraging managers to incorporate environmentalrelated goals into job descriptions and employee career goals. For example, Shervin-Williams Corporation guarantees that, the most important green criteria, such as energy consumption, waste generation, and recycling, are included in job descriptions and transmitted to specific staffing objectives and tasks (for example, tracking, reporting, licensing, site evaluation, research, and training) ${ }^{8)}$ AMANCO is a Latin American company that manufactures and sells plastic tubes and accessories every four months, conferences will be held to evaluate and discuss the performance of managers based on various criteria of performance rating cards, including environmental measures such as energy and water consumption per unit ${ }^{27)}$.

\subsection{Green reward and compensation:}

In a study conducted by CIPT / KPMG in the UK, $8 \%$ of institutions in the country rewarded green behaviors with a variety of awards or financial incentives and these practices have been effective in motivating employees to create environmental initiatives ${ }^{34)}$. In a similar study by Forman and Jorgensen (2001) about the importance of employee participation in environmental programs, it was observed that; employee participation in environmental management programs grew when they were rewarded with responsibilities for environmental responsibility. The development of effective financial incentives can be challenging by evaluating fair and accurate performance and behavior 12). If the compensation and green reward systems are adjusted to the HRM process, green culture can be advantaged in organizations. Managers can promote green behaviors among employees through the combination of green management elements in the rewards program 2, 65). Rewards should be given for promoting green behaviors in the workplace, lifestyle and reducing carbon footprints 66).

\subsection{Green staff motivation:}

Regarding the motivation of green employees, research has shown that a negative reinforcement for green performance has had reverse results and even led to environmental problems on the person's side. The development of a reward system is very important to encourage green performance, which is considered to be material or immaterial in the event of the achievement of the green targets set in the system of compensation and rewards. Attention to green issues not only raises the credibility of the organization but also reduces the number of costs. These rewards can be, for example, in the form of daily rewards or prizes from the company ${ }^{37)}$. HR managers have to encourage employees to participate and initiate green and ecofriendly ideas through empowering employees ${ }^{74}$ ).

\subsection{Green Participation and Employment Relationships:}

Employee participation in green initiatives increases the chances of better green management as it aligns employees' goals, capabilities, motivations, and perceptions with green management practices and systems ${ }^{71)}$. Management should create a work environment, in which employees can express their opinions on green issues freely because they are the ones who are primarily responsible for the ethical conduct of the business in the daily life of the organization ${ }^{6)}$ A survey conducted on 214 British organizations shows that management support and the possibility of employee participation, as the most common incentive for employees, create an interest in the environment ${ }^{2)}$. The achievement of green outcomes will largely depend on employees' willingness to collaborate ${ }^{72}$ ), as often, the best ideas come from the employees who work in that particular area ${ }^{73)}$.

\section{Methodology}

In this research, according to the objectives, a systematic review has been used to accurately and systematically identify all relevant studies ${ }^{49)}$. Initially search for online printed articles in databases and valid conferences based on related keywords such as Green Human Resource Management, Sustainable Human Resources Management, Eco-Friendly Human Resource Management, Human Resource Management, Green Human Resources, Sustainable human resources, human resources and sustainability inside our country and abroad during the period from 2009 to 2018. Internal articles were searched on bases like Sid, Magiran, Noormags and Civilica, and foreign articles in databases such as Emerald, Springer link, Wiley Online Library, Taylor and Francis Online (Routledge) and Elsevier, and 240 articles were selected. The abstract of the articles was then examined and the unrelated items were deleted (such as papers related to sustainability but they did not mention human resources) so 75 articles were left. The full text of the remaining articles was studied and examined, and repeated and unrelated ones were deleted. 32 articles remained in the final review, the protocol being presented below (Figure 1). These articles were classified according to the author or authors, year of publication, country, and title of the journal, article title, research method, functions, and effective factors in implementation and gaps. The analysis and presentation of the data are in the Tables 2, 3, 4, 5, 6 and the amounts of attention to the functions of the Green Human Resource Management are in Fig. 2. Based on this, the data from the selected papers are compared and finally the conclusions are drawn. The final interpretation of the results was entirely based on the findings of the research. 


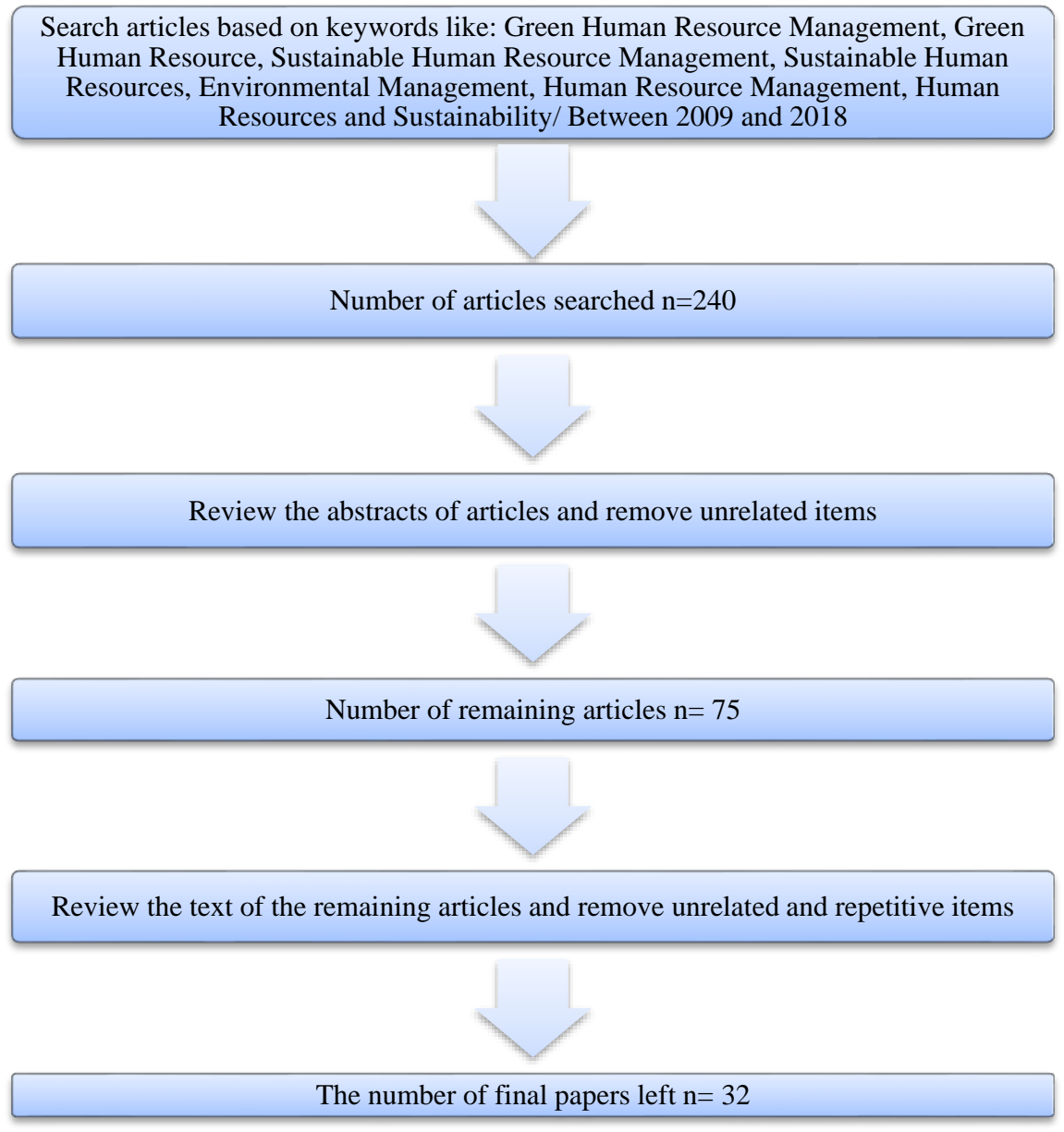

Figure 1: Process Workflow Protocol

\section{Results}

In Table 2 the title of the journal and article, the name of the researcher(s), the year of publication, the country in which the research has been carried out and the research method are cited by evaluating the full text of the selected articles, and also Table 3 shows the green HRM functions in detail that how each article focuses on which functions and Table 4 also illustrates how categorizing Green Human Resources Management functions are performed based on the titles and concepts of the functions listed in Table 3.

Table 5 and 6 represent which factors effect on implementing GHRM and what the mentioned gaps are.

The percentage of attention has been shown in Figure 2; so, that researchers who interest in the field of green human resources management can use this data to identify their future research background and cover the existing gaps and needs. Originally, the previous researches are summarized in these tables.

Table 2: A summary of previous studies conducted on GHRM during the past ten years

\begin{tabular}{|c|c|c|c|c|}
\hline Row & $\begin{array}{c}\text { Name of } \\
\text { researcher } \\
\text { / Year } \\
\text { /Country }\end{array}$ & Magazine title & Title of the article & Research method \\
\hline 1 & $\begin{array}{c}\text { Tavakoli et al / } \\
2018 / \text { Iran }\end{array}$ & $\begin{array}{c}\text { Journal of Research } \\
\text { in Human } \\
\text { Resources } \\
\text { Management }\end{array}$ & $\begin{array}{c}\text { Provide a Model of Green Human } \\
\text { Resource Management Based on Human } \\
\text { Resources Management Systems }\end{array}$ & $\begin{array}{c}\text { Descriptive-survey, } \\
\text { library study and } \\
\text { questionnaire }\end{array}$ \\
\hline 2 & $\begin{array}{c}\text { Patil \& Sarode / } \\
2018 / \text { India }\end{array}$ & $\begin{array}{c}\text { Journal of Creative } \\
\text { Research Thoughts } \\
\text { (IJCRT) }\end{array}$ & $\begin{array}{c}\text { Green Human Resource Management: } \\
\text { Role of HR Managers To Achieve } \\
\text { Sustainability }\end{array}$ & Systematic review \\
\hline 3 & $\begin{array}{c}\text { Tang et al / 2018 } \\
\text { / China }\end{array}$ & $\begin{array}{c}\text { Asia Pacific Journal } \\
\text { of Human }\end{array}$ & $\begin{array}{c}\text { Green human resource management } \\
\text { practices: scale development and validity }\end{array}$ & $\begin{array}{c}\text { Exploratory analysis } \\
\text { and factor analysis }\end{array}$ \\
\hline
\end{tabular}




\begin{tabular}{|c|c|c|c|c|}
\hline & & Resources & & \\
\hline 4 & $\begin{array}{l}\text { Hassanpoor et al } \\
\text { / } 2017 \text { / Iran }\end{array}$ & $\begin{array}{c}\text { Journal of } \\
\text { Environmental } \\
\text { Education \& } \\
\text { Sustainable } \\
\text { Development } \\
\end{array}$ & $\begin{array}{c}\text { Identifying and prioritizing the educational } \\
\text { needs of employees using the Network } \\
\text { Analysis Process (ANP) }\end{array}$ & Descriptive-survey \\
\hline 5 & $\begin{array}{l}\text { Rajabpoor / } \\
2017 \text { / Iran }\end{array}$ & $\begin{array}{c}\text { Journal of Research } \\
\text { in Human } \\
\text { Resources } \\
\text { Management } \\
\end{array}$ & $\begin{array}{l}\text { Impact of HRM on the development of } \\
\text { environmental management }\end{array}$ & $\begin{array}{l}\text { Survey-field } \\
\text { (questionnaire) }\end{array}$ \\
\hline 6 & $\begin{array}{l}\text { Seyed Javadin et } \\
\mathrm{al} / 2017 \text { / Iran }\end{array}$ & $\begin{array}{l}\text { Journal of } \\
\text { Investment } \\
\text { Knowledge }\end{array}$ & $\begin{array}{c}\text { Green Human Resource Management: An } \\
\text { Investment Approach and Sustainable } \\
\text { Development }\end{array}$ & $\begin{array}{c}\text { Qualitative and content } \\
\text { analysis }\end{array}$ \\
\hline 7 & $\begin{array}{l}\text { Mohammadneja } \\
\text { d et al / } 2017 \text { / } \\
\text { Iran } \\
\end{array}$ & $\begin{array}{l}\text { Journal of public } \\
\text { administration }\end{array}$ & $\begin{array}{c}\text { Provide a framework for human resource } \\
\text { management }\end{array}$ & $\begin{array}{l}\text { Qualitative research } \\
\text { (theme analysis) }\end{array}$ \\
\hline 8 & $\begin{array}{l}\text { Mishra / } 2017 \text { / } \\
\text { India }\end{array}$ & $\begin{array}{l}\text { International } \\
\text { Journal of } \\
\text { Organizational } \\
\text { Analysis (Emerald }\end{array}$ & $\begin{array}{l}\text { Green human resource Management A } \\
\text { framework for sustainable organizational } \\
\text { development in an emerging economy }\end{array}$ & Combined method \\
\hline 9 & $\begin{array}{c}\text { Masri \& Jaroon } \\
\text { / } 2017 \text { / } \\
\text { Palestine } \\
\end{array}$ & $\begin{array}{l}\text { Journal of Cleaner } \\
\text { Production } \\
\text { (Elsevier) } \\
\end{array}$ & $\begin{array}{c}\text { Assessing green human resources } \\
\text { management practices in Palestinian } \\
\text { manufacturing context: An empirical study }\end{array}$ & Empirical study \\
\hline 10 & $\begin{array}{c}\text { Paro Ragas et al } \\
\text { / 2017 / } \\
\text { Philippines }\end{array}$ & $\begin{array}{l}\text { International } \\
\text { Journal of } \\
\text { Productivity and } \\
\text { Performance } \\
\text { Management } \\
\text { (Emerald) } \\
\end{array}$ & $\begin{array}{l}\text { Green lifestyle moderates GHRM's impact } \\
\text { to job performance }\end{array}$ & $\begin{array}{l}\text { Modeling and analysis } \\
\text { Empirical factor }\end{array}$ \\
\hline 11 & $\begin{array}{l}\text { Gholami et al / } \\
2016 \text { / Malaysia }\end{array}$ & $\begin{array}{l}\text { Journal of Cleaner } \\
\text { Production } \\
\text { (Elsevier) }\end{array}$ & $\begin{array}{l}\text { State-of-the-art Green HRM System: } \\
\text { sustainability in the sports center in } \\
\text { Malaysia using a multi-methods approach } \\
\text { and opportunities for future research }\end{array}$ & Combined method \\
\hline 12 & $\begin{array}{l}\text { Abbasi et al / } \\
2016 \text { / Iran }\end{array}$ & $\begin{array}{l}\text { Third International } \\
\text { Conference on } \\
\text { Green Economics }\end{array}$ & $\begin{array}{c}\text { The Role of Governmental Organizations } \\
\text { in Green Productivity; From the Point of } \\
\text { View of Green Human Resource } \\
\text { Management }\end{array}$ & Review study \\
\hline 13 & $\begin{array}{c}\text { Jabbour \& } \\
\text { Jabbour / } 2016 \text { / } \\
\text { Brazil }\end{array}$ & $\begin{array}{l}\text { Journal of Cleaner } \\
\text { Production } \\
\text { (Elsevier) }\end{array}$ & $\begin{array}{c}\text { Green Human Resource Management and } \\
\text { Green Supply Chain Management: linking } \\
\text { two emerging agendas }\end{array}$ & Review study \\
\hline 14 & $\begin{array}{l}\text { O'Donohue \& } \\
\text { Torugsa / 2016 / } \\
\text { Australia }\end{array}$ & $\begin{array}{c}\text { The International } \\
\text { Journal of Human } \\
\text { Resource } \\
\text { Management } \\
\text { (Routledge) }\end{array}$ & $\begin{array}{c}\text { The moderating effect of 'Green' HRM on } \\
\text { the association between proactive } \\
\text { environmental management and financial } \\
\text { performance in small firms }\end{array}$ & Research paper \\
\hline 15 & $\begin{array}{c}\text { Guerci \& } \\
\text { Carollo / } 2016 \text { / } \\
\text { Italy }\end{array}$ & $\begin{array}{c}\text { The International } \\
\text { Journal of Human } \\
\text { Resource } \\
\text { Management } \\
\text { (Routledge) }\end{array}$ & $\begin{array}{c}\text { A paradox view on green human resource } \\
\text { management: insights from the Italian } \\
\text { context }\end{array}$ & $\begin{array}{l}\text { Qualitative research } \\
\text { with an interpretive } \\
\text { approach }\end{array}$ \\
\hline 16 & $\begin{array}{l}\text { Haddock-Millar } \\
\text { et al / 2016 / } \\
\text { America }\end{array}$ & $\begin{array}{c}\text { The International } \\
\text { Journal of Human } \\
\text { Resource } \\
\text { Management } \\
\text { (Routledge) }\end{array}$ & $\begin{array}{l}\text { Green human resource management: a } \\
\text { comparative qualitative case study of a } \\
\text { United States multinational corporation }\end{array}$ & Case study \\
\hline 17 & $\begin{array}{l}\text { Subramania et al } \\
\text { / } 2016 \text { / China }\end{array}$ & $\begin{array}{c}\text { The International } \\
\text { Journal of Human } \\
\text { Resource } \\
\text { Management } \\
\text { (Routledge) }\end{array}$ & $\begin{array}{l}\text { Green competence framework: evidence } \\
\text { from China }\end{array}$ & Quantitative Research \\
\hline
\end{tabular}




\begin{tabular}{|c|c|c|c|c|}
\hline 18 & $\begin{array}{l}\text { Renwick et al / } \\
2016 \text { / England }\end{array}$ & $\begin{array}{l}\text { The International } \\
\text { Journal of Human } \\
\text { Resource } \\
\text { Management } \\
\text { (Routledge) }\end{array}$ & $\begin{array}{l}\text { Contemporary developments in Green } \\
\text { (environmental) HRM scholarship }\end{array}$ & Theme Analysis \\
\hline 19 & $\begin{array}{l}\text { Tariq et al / } \\
2016 \text { / Pakistan }\end{array}$ & $\begin{array}{l}\text { Qual Quant } \\
\text { (Springer) }\end{array}$ & $\begin{array}{l}\text { Green employee empowerment: a } \\
\text { systematic Literature review on state-of-art } \\
\text { in green human resource management }\end{array}$ & Systematic review \\
\hline 20 & $\begin{array}{l}\text { Arz Bhutto \& } \\
\text { Auranzeb / } 2016 \\
\text { / Pakistan }\end{array}$ & $\begin{array}{c}\text { European Journal of } \\
\text { Business and } \\
\text { Management } \\
\text { (IISTE) }\end{array}$ & $\begin{array}{l}\text { Effects of Green Human Resources } \\
\text { Management on Firm Performance: An } \\
\text { Empirical Study on Pakistani Firms }\end{array}$ & $\begin{array}{l}\text { Review study and } \\
\text { structured questionnaire }\end{array}$ \\
\hline 21 & $\begin{array}{l}\text { Ahmad / } 2015 \text { / } \\
\text { Saudi Arabia }\end{array}$ & $\begin{array}{l}\text { Cogent Business \& } \\
\text { Management }\end{array}$ & $\begin{array}{l}\text { Green Human Resource Management: } \\
\text { Policies and practices }\end{array}$ & Systematic review \\
\hline 22 & $\begin{array}{l}\text { Mohd Yusoff et } \\
\text { al. / 2015 / } \\
\text { Malaysia }\end{array}$ & $\begin{array}{l}\text { International } \\
\text { Journal of Business } \\
\text { Management and } \\
\text { Economic Research } \\
\text { (IJBMER) } \\
\end{array}$ & $\begin{array}{c}\text { Conceptualization of Green Human } \\
\text { Resource Management: An Exploratory } \\
\text { Study from Malaysian-based Multinational } \\
\text { Companies }\end{array}$ & Qualitative method \\
\hline 23 & $\begin{array}{l}\text { Cheema et al / } \\
2015 \text { / Pakistan }\end{array}$ & $\begin{array}{l}\text { Journal of Business } \\
\text { Studies Quarterly } \\
\text { (JBSQ) }\end{array}$ & $\begin{array}{c}\text { Green Human Resource Practices: } \\
\text { Implementations and Hurdles of SMEs in } \\
\text { Pakistan }\end{array}$ & Quantitative research \\
\hline 24 & $\begin{array}{c}\text { Opatha \& } \\
\text { Arulrajah / } 2014 \\
\text { / Sri Lanka } \\
\end{array}$ & $\begin{array}{c}\text { International } \\
\text { Business Research }\end{array}$ & $\begin{array}{l}\text { Green Human Resource Management: } \\
\text { Simplified General Reflections }\end{array}$ & Systematic review \\
\hline 25 & $\begin{array}{l}\text { Milliman / } 2013 \\
\text { / America }\end{array}$ & $\begin{array}{l}\text { Environmental } \\
\text { Quality } \\
\text { Management } \\
\text { (Wiley) }\end{array}$ & $\begin{array}{l}\text { Leading-Edge Green Human Resource } \\
\text { Practices: Vital Components to Advancing } \\
\text { Environmental Sustainability }\end{array}$ & Review study \\
\hline 26 & $\begin{array}{l}\text { Marques Pereira } \\
\text { et al / } 2013 / \\
\text { Brazil }\end{array}$ & $\begin{array}{c}\text { International } \\
\text { Journal of } \\
\text { Sustainability in } \\
\text { Higher Education } \\
\text { (Emerald) } \\
\end{array}$ & $\begin{array}{l}\text { Greening the campus of a Brazilian } \\
\text { university: cultural challenges }\end{array}$ & Case study \\
\hline 27 & $\begin{array}{l}\text { Wagner / } 2013 \text { / } \\
\text { Germany }\end{array}$ & $\begin{array}{l}\text { J Bus Ethics } \\
\text { (Springer) }\end{array}$ & $\begin{array}{l}\text { Green Human Resource Benefits: Do they } \\
\text { Matter as Determinants of Environmental } \\
\text { Management System Implementation? }\end{array}$ & Empirical Research \\
\hline 28 & $\begin{array}{l}\text { Renwick et al / } \\
2012 \text { / England }\end{array}$ & $\begin{array}{l}\text { International } \\
\text { Journal of } \\
\text { Management } \\
\text { Reviews (IJMR) }\end{array}$ & $\begin{array}{l}\text { Green Human Resource Management: A } \\
\text { Review and Research Agenda }\end{array}$ & Systematic Review \\
\hline 29 & $\begin{array}{c}\text { Dabois \& } \\
\text { Dabois / 2012 / } \\
\text { America } \\
\end{array}$ & $\begin{array}{l}\text { Human Resource } \\
\text { Management } \\
\text { (Wiley) }\end{array}$ & $\begin{array}{l}\text { Strategic HRM as Social design for } \\
\text { environmental sustainability in } \\
\text { organization } \\
\end{array}$ & Review study \\
\hline 30 & $\begin{array}{l}\text { Jackson et al / } \\
2011 / \text { America, } \\
\text { Britain and } \\
\text { Brazil }\end{array}$ & $\begin{array}{l}\text { Zeitschrift für } \\
\text { Personalforschung }\end{array}$ & $\begin{array}{l}\text { State-of-the-art and future directions for } \\
\text { green human resource management: } \\
\text { introduction to the special issue }\end{array}$ & Review and Discussion \\
\hline 31 & $\begin{array}{c}\text { Jabbour et al / } \\
2010 \text { / Brazil }\end{array}$ & $\begin{array}{c}\text { The International } \\
\text { Journal of Human } \\
\text { Resource } \\
\text { Management } \\
\text { (Routledge) }\end{array}$ & $\begin{array}{l}\text { Contributions of HRM throughout the } \\
\text { stages of environmental management: } \\
\text { methodological triangulation applied to } \\
\text { companies in Brazil }\end{array}$ & Combined method \\
\hline 32 & $\begin{array}{c}\text { Ehnert / } 2009 \text { / } \\
\text { Germany }\end{array}$ & $\begin{array}{l}\text { European J. } \\
\text { International } \\
\text { Management }\end{array}$ & $\begin{array}{l}\text { Sustainability and human resource } \\
\text { management: reasoning and applications } \\
\text { on corporate websites }\end{array}$ & Content analysis \\
\hline
\end{tabular}

Table 3: Brief description of studies analyzed on the functions of GHRM

\begin{tabular}{|c|l|}
\hline Author/ year & \multicolumn{1}{c|}{ Functions of GHRM } \\
\hline $\begin{array}{c}\text { Tavakoli et al / } \\
2018\end{array}$ & $\begin{array}{l}\text { Maintenance, compensation, performance management, training and development, employee } \\
\text { relations }\end{array}$ \\
\hline $\begin{array}{c}\text { Patil \& Sarode / } \\
2018\end{array}$ & $\begin{array}{l}\text { Green employment, green performance management, green training and development, green } \\
\text { compensation and employee participation }\end{array}$ \\
\hline
\end{tabular}




\begin{tabular}{|c|c|c|}
\hline Tang et al / 2018 & \multicolumn{2}{|c|}{$\begin{array}{l}\text { Green selection and employment, green training, green performance management, green payment } \\
\text { and green reward, green participation }\end{array}$} \\
\hline Rajabpoor / 2017 & \multicolumn{2}{|c|}{$\begin{array}{l}\text { Recruitment, training and development, performance appraisal, compensation, benefits and } \\
\text { rewards, employee relationships. }\end{array}$} \\
\hline $\begin{array}{l}\text { Seyed Javadin et al } \\
\qquad / 2017\end{array}$ & \multicolumn{2}{|c|}{ Green selection and employment, green training, reward system. } \\
\hline $\begin{array}{l}\text { Mohammadnejad et } \\
\text { al / } 2017\end{array}$ & \multicolumn{2}{|c|}{ Green attraction, green performance evaluation, green development, green retention } \\
\hline Mishra / 2017 & \multicolumn{2}{|c|}{$\begin{array}{l}\text { Green selection and employment, green training, green performance assessment, green } \\
\text { participation and compensation }\end{array}$} \\
\hline $\begin{array}{l}\text { Masri \& Jaroon / } \\
\quad 2017\end{array}$ & \multicolumn{2}{|c|}{$\begin{array}{l}\text { Green selection and employment, green training and development, green performance } \\
\text { management and evaluation, green compensation, green participation and empowerment, green } \\
\text { management of organizational culture }\end{array}$} \\
\hline $\begin{array}{l}\text { Gholami et al / } \\
2016\end{array}$ & \multicolumn{2}{|c|}{$\begin{array}{l}\text { Performance management, participation and empowerment, payment and reward system, } \\
\text { recruitment, training and development. }\end{array}$} \\
\hline Abbasi et al / 2016 & \multicolumn{2}{|c|}{$\begin{array}{l}\text { Green job analysis, green selection and employment, green socialization, green education, green } \\
\text { performance evaluation, green reward management, green discipline management, green } \\
\text { relationships. }\end{array}$} \\
\hline $\begin{array}{l}\text { Guerci \& Carollo / } \\
\qquad 2016\end{array}$ & \multicolumn{2}{|c|}{$\begin{array}{l}\text { Recruitment, selection, training, performance management, rewards and compensation, } \\
\text { participation, job design. }\end{array}$} \\
\hline $\begin{array}{l}\text { Subramania et al / } \\
2016\end{array}$ & \multicolumn{2}{|c|}{ Green selection and employment, green development and training, green performance evaluation } \\
\hline $\begin{array}{l}\text { Renwick et al / } \\
2016\end{array}$ & \multicolumn{2}{|c|}{$\begin{array}{l}\text { Green selection and employment, development and training, participation, motivation, } \\
\text { performance evaluation, leadership, communications, compensation. }\end{array}$} \\
\hline $\begin{array}{c}\text { Arz Bhutto \& } \\
\text { Auranzeb / } 2016\end{array}$ & \multicolumn{2}{|c|}{ Green employment, green training and development, green learning. } \\
\hline Ahmad / 2015 & \multicolumn{2}{|c|}{$\begin{array}{l}\text { Green selection and employment, green performance management, green development an } \\
\text { training, green compensation, green relationships, green initiatives }\end{array}$} \\
\hline $\begin{array}{l}\text { Mohd Yusoff et al. } \\
\qquad / 2015\end{array}$ & \multicolumn{2}{|c|}{ Employment, training, performance evaluation, motivation, compensation } \\
\hline Cheema et al / 2015 & \multicolumn{2}{|c|}{ Employment, training and development, performance management } \\
\hline $\begin{array}{l}\text { Opatha \& Arulrajah } \\
\qquad / 2014\end{array}$ & \multicolumn{2}{|c|}{$\begin{array}{l}\text { Job analysis, selection and recruitment, socialization, education, performance evaluation, rewarc } \\
\text { management, discipline management }\end{array}$} \\
\hline Milliman / 2013 & $\begin{array}{l}\text { Selection and } 1 \\
\text { rewards, sociali }\end{array}$ & $\begin{array}{l}\text { ruitment, training and development, work teams, performance } \\
\text { ion. }\end{array}$ \\
\hline Wagner / 2013 & Recruitment, m & tenance \\
\hline $\begin{array}{l}\text { Renwick et al / } \\
2012\end{array}$ & $\begin{array}{l}\text { Recruitment, g1 } \\
\text { green leadershi } \\
\text { opportunities ar }\end{array}$ & $\begin{array}{l}\text { n education, development and leadership development, green kno } \\
\text { performance evaluation and management, payment system and rev } \\
\text { participation }\end{array}$ \\
\hline $\begin{array}{l}\text { Dabois \& Dabois / } \\
\qquad 2012\end{array}$ & $\begin{array}{l}\text { Selection and } \mathrm{r} \\
\text { rewards, partici }\end{array}$ & $\begin{array}{l}\text { ruitment, training and development, evaluation and performance } \mathrm{m} \\
\text { tion }\end{array}$ \\
\hline Jackson et al / 2011 & $\begin{array}{l}\text { Employment, } \\
\text { services }\end{array}$ & ormance management, training and development, reward and \\
\hline Jabbour et al / 2010 & Analysis and jo & description, selection, recruitment, training, performance evaluation, \\
\hline & Table 4: & ssification of the functions cited in reviewed articles \\
\hline & analysis & Job analysis, job design, job description \\
\hline & $\begin{array}{l}\text { ction and } \\
\text { ruitment }\end{array}$ & Selection and employment, recruitment, attraction \\
\hline & ialization & Management of organizational culture \\
\hline & $\begin{array}{l}\text { ining and } \\
\text { elopment }\end{array}$ & $\begin{array}{l}\text { Training and development, learning, empowerment, green } \\
\text { knowledge }\end{array}$ \\
\hline & $\begin{array}{l}\text { formance } \\
\text { nagement }\end{array}$ & $\begin{array}{l}\text { Performance evaluation, performance management, performance } \\
\text { appraisal }\end{array}$ \\
\hline $\begin{array}{r}\text { ReI } \\
\text { col }\end{array}$ & $\begin{array}{l}\text { arding and } \\
\text { pensation }\end{array}$ & $\begin{array}{l}\text { Rewards, benefits, compensation, green initiatives, motivation, } \\
\text { payment }\end{array}$ \\
\hline & etention & Retention, maintenance \\
\hline $\begin{array}{r}\text { Part } \\
\text { workir }\end{array}$ & $\begin{array}{l}\text { pation and } \\
\text { relationships }\end{array}$ & Participation, work teams, leadership, communications \\
\hline Discipli & e management & Discipline, discipline management \\
\hline
\end{tabular}




\section{Percentage of attention}

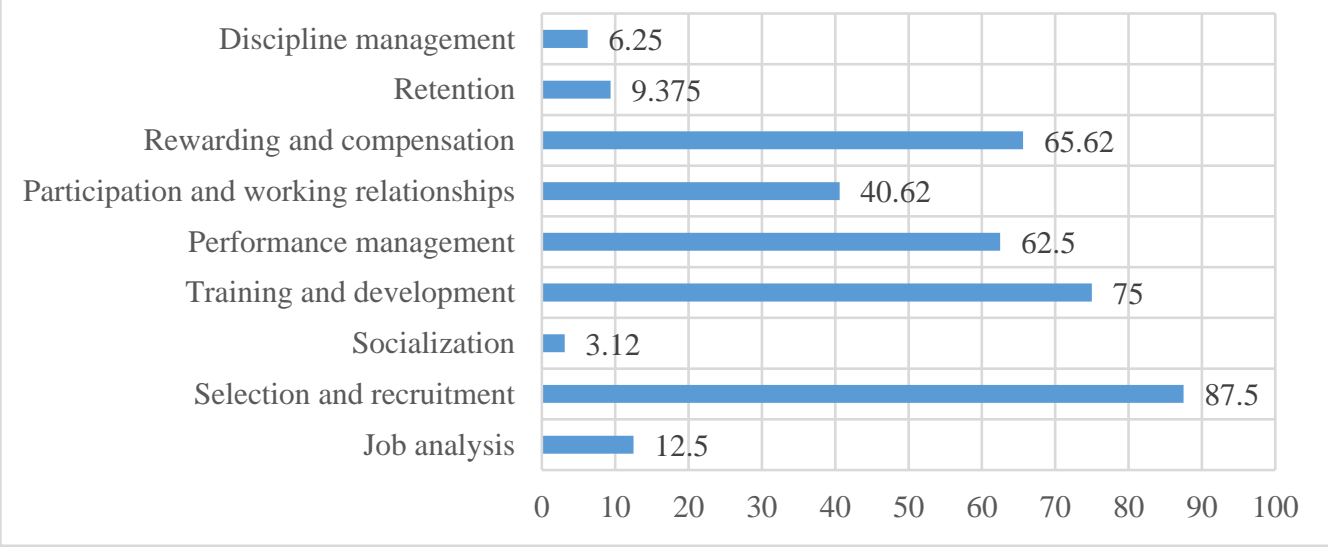

Figure 2: The Attention of Recent 10-Year Articles to Green Human Resource Management Functions

As shown in Figure 2, the researchers have focused on selection and recruitment, training and development with $87.5 \%$ and $75 \%$, in human resource management in their research. After that, the rewarding and compensation function with $65.62 \%$, performance management is $62.5 \%$, participation and working relationships is
$40.62 \%$, job analysis $12.5 \%$, retention $9.37 \%$ and the least attention are paid to the discipline management with $6,25 \%$ and socialization of employees with $3.12 \%$.

Table 5: The effective factors to implement GHRM cited in reviewed articles

\begin{tabular}{|c|c|c|}
\hline Row & Factors & Author \\
\hline 1 & Quality and methods of compensation & Tavakoli et al. (2018) \\
\hline 2 & Financial and non-financial motivation & $\begin{array}{l}\text { Tavakoli et al. (2018), Milliman (2013), Gholami et al. (2016), } \\
\text { O'Donohue \& Torugsa (2016), Haddock-Millar et al. (2016), } \\
\text { Renwick et al. (2012), }\end{array}$ \\
\hline 3 & Feedback for green programs & Tavakoli et al. (2018) \\
\hline 4 & Green organizational learning & $\begin{array}{c}\text { Rajabpoor (2017), Mishra (2017), O'Donohue \& Torugsa } \\
\text { (2016), Guerci \& Carollo (2016), Renwick et al. (2016), } \\
\text { Cheema et al. (2015), Renwick et al. (2012) }\end{array}$ \\
\hline 5 & Green technology & Patil \& Sarode (2018) \\
\hline 6 & Social responsibility & $\begin{array}{c}\text { Hassanpoor et al. (2017), Mishra (2017), Tariq et al. (2016), } \\
\text { Mohd Yusoff et al. (2015), Milliman (2013), Wagner (2013), } \\
\text { Ehnert (2009), Guerci \& Carollo (2016) }\end{array}$ \\
\hline 7 & Citizenship behavior & $\begin{array}{l}\text { Hassanpoor et al. (2017), Mohammadnejad et al. (2017), } \\
\text { Haddock-Millar et al. (2016), Tariq et al. (2016), Renwick et al. } \\
\text { (2016), Cheema et al. (2015), Milliman (2013) }\end{array}$ \\
\hline 8 & $\begin{array}{l}\text { Green management and leadership } \\
\text { support of green ideas and activities }\end{array}$ & $\begin{array}{c}\text { Patil \& Sarode (2018), Hassanpoor et al. (2017), } \\
\text { Mohammadnejad et al. (2017), Mishra (2017), Jabbour \& } \\
\text { Jabbour (2016), Milliman (2013), Dabois \& Dabois (2012) }\end{array}$ \\
\hline 9 & $\begin{array}{l}\text { Green laws and regulations, ethics and } \\
\text { standards }\end{array}$ & Hassanpoor et al. (2017), Rajabpoor (2017) \\
\hline 10 & Organizational identity and brand & $\begin{array}{c}\text { Rajabpoor (2017), Mohammadnejad et al. (2017), Haddock- } \\
\text { Millar et al. (2016), Milliman (2013) }\end{array}$ \\
\hline 11 & Organizational attitudes and culture & $\begin{array}{l}\text { Rajabpoor (2017), Dabois \& Dabois (2012), Jackson et al. } \\
\text { (2011) }\end{array}$ \\
\hline 12 & Green initiative, creativity and innovation & $\begin{array}{c}\text { Tavakoli et al. (2018), Seyed Javadin et al. (2017), O'Donohue } \\
\text { \& Torugsa (2016), Wagner (2013) }\end{array}$ \\
\hline 13 & Industry type & Mohammadnejad et al. (2017) \\
\hline 14 & Competitive advantage strategy & $\begin{array}{c}\text { Mishra (2017), Subramania et al. (2016), Renwick et al. (2016), } \\
\text { Tariq et al. (2016), Jabbour et al. (2010) }\end{array}$ \\
\hline 15 & $\begin{array}{l}\text { Acceptance and willingness of staff, staff } \\
\text { attitudes }\end{array}$ & Mohammadnejad et al. (2017), Mishra (2017) \\
\hline 16 & Flexible, democratic and open structure & O'Donohue \& Torugsa (2016), Jabbour \& Jabbour (2016), \\
\hline
\end{tabular}




\begin{tabular}{|c|c|c|}
\hline & & $\begin{array}{c}\text { Guerci \& Carollo (2016), Haddock-Millar et al. (2016), } \\
\text { Haddock-Millar et al. (2016), Tariq et al. (2016), Milliman } \\
\text { (2013), Dabois \& Dabois (2012) }\end{array}$ \\
\hline 17 & Commitment and green responsibility & $\begin{array}{c}\text { O'Donohue \& Torugsa (2016), Haddock-Millar et al. (2016), } \\
\text { Tariq et al. (2016) }\end{array}$ \\
\hline 18 & $\begin{array}{l}\text { Green missions, strategies, goals and } \\
\text { policies }\end{array}$ & $\begin{array}{l}\text { Tavakoli et al. (2018), O'Donohue \& Torugsa (2016), Arz } \\
\text { Bhutto \& Auranzeb (2016), Ahmad (2015), Milliman (2013) }\end{array}$ \\
\hline 19 & Job satisfaction & Tariq et al. (2016), Wagner (2013) \\
\hline 20 & Demographic factors & Arz Bhutto \& Auranzeb (2016), Cheema et al. (2015) \\
\hline 21 & Green investments & $\begin{array}{l}\text { Haddock-Millar et al. (2016), Cheema et al. (2015), Jackson et } \\
\text { al. (2011) }\end{array}$ \\
\hline 22 & Long-term vision for green issues & Haddock-Millar et al. (2016), Milliman (2013) \\
\hline 23 & Size of company and number of employees & Wagner (2013) \\
\hline 24 & $\begin{array}{l}\text { Organization's accountability } \\
\text { transparency }\end{array}$ & Ehnert (2009) \\
\hline
\end{tabular}

Table 6: Brief description of the gaps have been mentioned in the articles

\begin{tabular}{|l|c|}
\hline \multicolumn{1}{|c|}{ Gaps } & Frequency \\
\hline $\begin{array}{l}\text { Lack of comprehensive studies and research about GHRM in undeveloped countries and } \\
\text { Asia }\end{array}$ & 14 \\
\hline The absence of a cross-cultural model & 5 \\
\hline The lack of long term comparison between sustainable companies and unsustainable ones & 3 \\
\hline Lack of attention to rewards for green activities and how to motivate green HR & 2 \\
\hline Lack of up to date green training & 2 \\
\hline Little attention to green leadership & 2 \\
\hline Disconnection between the behavior of managers and GHRM & 1 \\
\hline Lack of sufficient knowledge of benefits of GHRM & 1 \\
\hline
\end{tabular}

\section{Discussion of Results}

Based on the findings of this study (Table 2, 3, 4, 5, 6), it is found that the main gaps in the research on green human resources management are the lack of comprehensive research in undeveloped countries and Asia, and the absence of a cross cultural model. For example, Tavakkoli et al. (2018), Rajabpour (2017), Seyed Javadin et al. (2017), and Mohammad Nejad et al. (2017) have pointed to the existence of few studies in this area in Iran and the lack of a codified program; Mishra (2017), Masri \& Jarron (2017), Tariq et al. (2016), Mohd Yusuf et al. (2015), Wagner (2013) and Renwick et al. (2012) have stated that most of the researches on human resource management are in developed countries, European countries and the United States; Gholami et al (2016), Subramaniana et al (2016), and Opatha and Arulrajah (2014) respectively have referred to the lack of comprehensive research in Malaysia, China, Sri Lanka, and Cheema et al. (2015) also lack of sufficient knowledge of the benefits of green human resource management in Pakistan is a major gap knows. On the other hand, Tang et al. (2018), Patil and Sarode (2018), Subramaniana et al. (2016) and Cheema et al. (2015), lack of a mutually international model.

There is also a major need for more attention to the issue of leadership, rewards, training and more generally the attention of managers to the management of green human resources and the need to address these needs in Tang et al. (2018), Hassanpour et al. (2017) Mishra (2017), Masri and Jarron (2017), Paro Ragas et al.
(2017), Ahmed (2015) and Renwick et al. (2012) and the lack of a long-term comparison between sustainable and non-sustainable companies has been mentioned in the research of Renwick et al. (2016), Odonohuea and Torugsa (2016) and Ehnert (2009), which are among the other existing gaps.

On the other hand, according to Figure 2, it has been determined that the functions of selection and recruitment, training and development, in the management of green human resources have the most attention and the functions of discipline management and socialization have devoted the least attention. It is suggested that more attention should be paid to the functions of discipline management and socialization and their impact on human resource management in future research, because the functions of green human resources management are all complementary and affect each other and it is necessary to take into account all the functions of Green Human Resource Management in terms of organization size, employee characteristics and organizational culture. Of course, it may be necessary to further examine which functions are important in green human resource management and more affected by the green behavior of employees.

\section{Conclusions and Future Research Work}

Those human resources are the most important asset of an organization and human resource management plays an important role in the organization is an irrefutable fact. Recently, the trend of increasing the 
focus of organizations on the growth of business and HR managers has increased. Although the Green Movement and Green Human Resources are still in the early stages and growing awareness in organizations, however, the importance of green issues has made organizations more likely to make use of Green Human Resource Management ${ }^{2)}$. Our goal is also to develop knowledge in the field of human resource management. So, with a systematic review of previous research, the research tabulation has been based on the author's title, article and journal, research methodology, functions and factors influencing the implementation of green human resources management and gaps. By doing this research, we have been trying to take a positive step forward in advancing the philosophy of human resource management and its outcomes are the prospect for future research by reviewing the findings from this study, future researchers will look at existing gaps and issues of green human resource management that still need to be further explored and less addressed.

The findings show that there is still a need for more research in the area of human resource management and the needs and gaps in it, this research cited the bulk of these gaps, which will enable us to make further efforts to further develop the concept of green human resources management and how to apply it. In addition the benefits of this area has for human resources and the organization, it also helps to protect the environment, therefore, it is suggested that due to the lack of cross-cultural model and the lack of comparative research on the international level, the main gap mentioned above, the researchers will further explore this and design a comprehensive model that fills this gap as well as to examine and compare the implementation and application of green human resources management in Asian and Western countries and also in developed and undeveloped countries. It also brings about the development of the concept of human resource management, both green and more user-friendly

\section{References}

1) T. Abbasi, G. Jamali and H. Azari, 3th Intl Conf on G.Es, (2016).

2) S. Ahmad, Cogent Buss \& Mgmt, 2, 1 (2015).

3) S. Arz Bhutto and Auranzeb, Eur. J. of Buss and Mgmt, 8, 119, (2016).

4) T. Bauer, B. Erdogan and S. Taylor, Creating and maintaining environmentally sustainable organizations: Recruitment and on-boarding, In S. Jackson, D. Ones, \& S. Dilchert (Eds.), Managing human resources for environmental sustainability, NY: Wiley, New York, (2012).

5) S. Cheema, A. Tisman Pasha and F. Javed, J. of Buss. Studies Quarterly, 7, 231, (2015).

6) J. Collier and R. Esteban, Buss. Ethics: An Eur. Rvw., 16, 19, (2007),
7) B. F. Daily and S. Huang, Intl. J. of Oprtn. \& Prdc. Mgmt., 21, 1539, (2001).

8) C. Dubois, EcoVision at Sherwin-Williams: Leadership at all levels. In S. Jackson, D. Ones, \& S. Dilchert (Eds.), Managing human resources for environmental sustainability, NY: Wiley, New York, (2012).

9) C. L. Z. Dubois and D. A. Dubois, Wiley, 51, 799, (2012).

10)S. Dutta, ZENITH: Intl. J. of Buss. Ecmcs. \& Mgmt Research, 2, 143, (2012).

11)I. Ehnert, Eur. J. Int. Mgmt, 3, 419, (2009).

12)E. Fernandez, B. Junquera and M. Ordiz, Intl. J. of $H R M$, 14, 634, (2003).

13)M. Forman and S. Jorgensen, J. of Techno Anlys \& Strg. Mgmt, 13, 71, (2001).

14)H. Gholami, G. Rezaei, M. Zameri Mat Saman, S. Sharif, N. Zakuan, J. of Cleaner Prdc, Elsevier, 124, 142, (2016).

15)J. Gonzalez-Benito and O. Gonzalez-Benito, J. of Buss. Strg and the Environment, 15, 87, (2006).

16) M. Guerci and L. Carollo, The Intl J. of HRM, 27, 212, (2016)

17)J. Haddock-Millar, C. Sanyal, and M. Müller-Camen, The Intl J. of HRM, 27, 192, (2016)

18)A. Hamilton, D.A. Gioia, Fostering sustainabilityfocused organizational identities, first edition, Routledge, New York, (2009).

19)A. Hassanpoor, S.A. Abtahi and F. Khamoie, J. of Environmental Edu. \& Sustainable Dvpl, 6, 9, (2017).

20)C.J.C. Jabbour, F.C.A. Santos and M.S. Nagano, Intl J. of HRM, 21, 1049, (2010).

21)C.J.C. Jabbour and A.B.L.D.S. Jabbour, J. of Cleaner Prdc, Elsevier, 112, 1824, (2016).

22)S. E. Jackson, D. W. S. Renwick, C. J. C. Jabbour and M. Muller-Camen, German J/ of Research in $H R M, 25,(2011)$.

23)K. H. Lee, Mgmt Decision, 47, 1101, (2009).

24)A. Marcus and R. Fremeth, Academy of Mgmt Perspectives, 23, 17, (2009).

25)G. S. Marques Pereira, C. Jabbour, S. V. W. Borges de Oliveira and A. Alves Teixeira, Intl J. of Sustainability in Higher Edu, Emerald, 15, 34, (2012).

26)H. Masri and A. Jaaron, J. of Cleaner Prdc, Elsevier, 143, 474, (2017).

27)J. Milliman, Environmental Qulty Mgmt, Wiley, 23, 31, (2013). 
28)P. Mishra, Intl J. of Organizational Anlys., Emerald, 25, 762, (2017).

29)M. Mohammadnejad Shoorkaie, R. Seyed Javadin, M. Shah Hoseini and A. Hal Karimi, J. of Public Admin., 8, 691, (2017).

30) Y. Mohd Yusoff, N. Zahiyah Othman, Y. Fernando and A. Amran, Intl J. of Buss. Mgmt and Ecmc Research (IJBMER), 6, 158, (2015).

31)W. O'Donohuea, N. Torugsa, the Intl J. of HRM, Routledge, 27, 239, (2016).

32)H. Opatha and A. Arulrajah, Intl Buss Research, 7, (2014).

33)S. Paro Ragas, F. Angub Tantay, L. Co Chua and C. Concha Sunio, Intl J. of Productivity and Performance Mgmt, Emerald, 66, 857, (2017).

34)L. Phillips, People Mgmt, 13, (2007).

35)E. Rajabpoor, J. of Research in HRM, Imam Husein University, 9, 51, (2017).

36)D. Renwick, T. Redman and S. Maguire S, Green HRM: A Review, Process Model, and Research Agenda, University of Sheffield Management School, http://www.sheffield.ac.uk/content/1/c6/08/70/89/200 8-01.pdf. (2008).

37)D. Renwick, T. Redman and S. Maguire, Intl J. of Mgmt. reviews, 15, 1, (2012).

38)D. W.S. Renwick, T. Redman, C. J.C. Jabbour, M. Muller-Camen and A. Wilkinson, Intl J. of HRM, 27, 114, (2016).

39)T. Rokos, G. Rokos and L. Pellet, Sustainable staffing, Avocado Press. (2012).

40)W. Russell, Engaging employees in social consciousness at Eileen Fisher, InJ. Wirtenberg, W. Russell, \& D. Lipsky (Eds.), the sustainable enterprise fieldbook: When it all comes together, AMACOM, New York, (2008).

41)S.M. Scheiner and M.R. Willige, The theory of ecology, The University of Chicago Press, USA. (2011).

42)R. Seyed Javadin, T. Roshandel Arbatani and A. Nobari, J. of Invsmt Knowledge, Iranian Financial Engr Association, 5, 297, (2017).

43)H. Shipton, P. S. Budhwar and J. Crawshaw, Thunderbird Intl Buss. Review, Wiley, 54, 777, (2012).

44)G. Spreitzer, K. Sutcliff, J. Dutton, S. Sonenshine and A.M. Grant, Org. Science, 16, 537, (2005).

45)N. Subramaniana, M.D. Abdulrahmana, L. Wua and P. Nath, Intl J. of HRM, Routledge, 27, 151, (2016).

46)K. Mehta and C. Pawan Kumar, Universal J. of Industrial and Buss Mgmt, 3, 74, (2015).
47)G. Tang, Y. Chen, Y. Jiang, P. Paille and J. Jia, Asia Pacific J. of HR, Wiley, 56, 31, (2018).

48)S. Tariq, F. Ali Jan and M. Shakil Ahmad, Qual Quant, Springer, 50, 237, (2016).

49) A. Tavakoli, A. Hashemi, A. Sabet and S. Razeghi, J. of Research in HRM, Imam Husein University, 10, 75, (2018).

50)D. Tranfield, D. Denyer and P. Smart, British J. of Mgmt, 14, 207, (2003).

51)M. Wagner, J. of Buss. Ethics, Springer, 114, 114, (2013).

52)W. Wehrmeyer, Greening people, Greenleaf Publishing, Sheffield. (1996).

53)J. Patil and A.P. Sarode, Intl J. of Creative Research Thoughts (IJCRT), 6, 527, (2018).

54)S.E. Jackson and J. Seo, Organ. Manag .J. 7, 278, (2010).

55)D.S. Ones and S. Dilchert, Organ. Psychol, 5, 444, (2012).

56)S.E. Jackson, R.S. Schuler and K. Jiang, Acad. Mgmt. Ann, 1 (just-accepted), (2014).

57)C.J.C. Jabbour, Resour. Conserv. Recycl. 74, 144, (2013).

58)M. Thürer, M. Godinho Filho, M. Stevenson and L.D. Fredendall, Ind. Mgmt. Data Syst., 113, 856, (2013).

59)N. Govindarajulu and B.F. Daily, Ind. Mgmt. Data Syst. 104, 364, (2004).

60)R. Schuler and S.E. Jackson, J. Organ. Eff. People Perform, 1, 35, (2014).

61)P.D. Jennings and P.A. Zandbergen, Acad. of Mgmt. Review, 20, 1015, (1995).

62)C. Ichniowski, K. Shaw and G. Prennushi, The American Ecmc. Review, 87, 291, (1997).

63)H. Mendelson, and R.R. Pillai, J. Ecmc. Behavior and Org, 38, 253, (1999).

64)C.J. Collins and K.D. Clark, Acad. Mgmt. J., 46, 740, (2003).

65)P. Berrone and L.R. Gomez-Mejia, Acad. Mgmt. J., 52, 103, (2009).

66)R. Pillai and B. Sivathanu, Zenith Intl. J. Multidisciplinary Research, 4, 72, (2014).

67) A.A. Teixeira, C.J.C. Jabbour and A.B.L. de Sousa Jabbour, Intl. J. Prdc. Ecmcs, 140, 318, (2012).

68)B.W. Jacobs, V.R. Singhal and R. Subramanian, J. Oprt. Mgmt, 28, 430, (2010).

69)B.C. Holtom, T.R. Mitchell, T.W. Lee and M.B. Eberly, Acad. Mgmt. Ann., 2, 231, (2008).

70)D. Zoogah, Zeitschrift fur Personalforschung, 25, 117, (2011). 
71)R. Florida and D. Davison, California Mgmt. Review, 43, 64, (2001).

72)J. Collier and R. Esteban, Buss. Ethics: A Eur. Review, 16, 19, (2007).

73)A. Casler, M.J. Gundlach, B. Persons and S. Zivnuska, People \& Strgy, 33, 44, (2010).

74)C.J.C. Jabbour and F.C.A. Santos, Relationships between human resource dimensions and environmental management in companies: proposal of a model, (2008a).

75)K. Hersey, Professional Safety, 43, 26, (1998). 